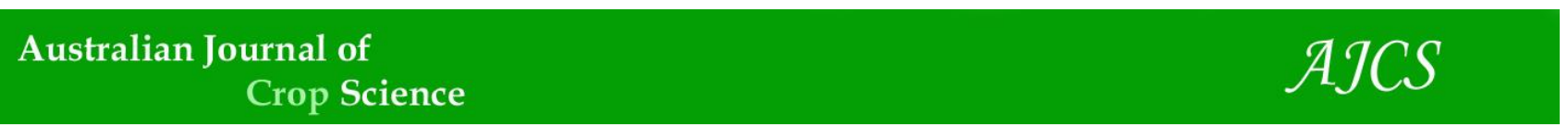

AJCS 14(12):1913-1919 (2020)

ISSN:1835-2707

doi: 10.21475/ajcs.20.14.12.2746

\title{
Effects of Azospirillum brasilense applied along with herbicides on maize
}

\author{
María Albana Di Palma ${ }^{1}$, Paula Cardozo ${ }^{1}$, Soledad Martin ${ }^{1}$, Herminda Reinoso ${ }^{1}$, Marta Dardanelli ${ }^{2}$, Claudia \\ Travaglia ${ }^{1^{*}}$
}

\author{
${ }^{1}$ Área Botánica, Departamento de Ciencias Naturales, Facultad de Ciencias Exactas, Físico Químicas y Naturales, \\ Universidad Nacional de Río Cuarto-Instituto de Investigación Agrobiotecnológicas (INIAB), Córdoba, Argentina \\ ${ }^{2}$ Departamento de Biología Molecular, Facultad de Ciencias Exactas, Físico Químicas y Naturales, Universidad \\ Nacional de Río Cuarto, Córdoba, Argentina
}

\section{*Corresponding author: ctravaglia@exa.unrc.edu.ar}

\begin{abstract}
The aim of this work was a study of a native strain (Az39) and a reference strain (Sp7) of Azospirillum brasilense, evaluating their effects on commercial herbicides like glyphosate and atrazine applied in maize. In vitro assays were performed to determine the survival capacity of both strains by adding each herbicide with and without the addition of carbon or nitrogen. A growth chamber experiment was carried out with maize plants, and the treatments consisted on applications of atrazine and glyphosate, with and without foliar inoculations of each strain. Morpho-physiological variables were determined in V6. The in vitro assays determined that the survival capacity of both strains was different in the presence of herbicides; Az39 was the only one able to survive both to the application of glyphosate and atrazine and was able to use glyphosate as the sole source of carbon. In maize plants, both herbicides affected the foliar area, the aerial and the radical biomass negatively and increased the damage of cell membranes. Most of the negative effects of both agrochemicals were mitigated with Az39, while both strains ameliorated the damage at the radical biomass. Therefore, the native strain has better adaptive characteristics against herbicides widely used in maize. This highlights the importance of the use of native microorganisms for effective inoculations in crops.
\end{abstract}

Keywords: Foliar inoculation, Bacterial strains, Zea mays, Xenobiotic, Growth.

Abbreviations: Az39_native strain of Azospirillum brasilense; Sp7_reference strain of A. brasilense; DW_dry weight; FW_fresh weight; RCR_relative conductivity rate; CFU_colony forming unit; OD: optical density; PGPR_Plant Growth Promoting Rhizobacteria.

\section{Introduction}

In recent years, the use of beneficial microorganisms has been widely recognized due to its positive effects on the yield of many crops and the feasibility of developing a sustainable agriculture (García et al., 2017). Studies carried out for more than 20 years indicate that bacteria of the genus Azospirillum have a strong affinity for the roots of Poaceas (Mehnaz, 2015), highlighting their ability to stimulate plant growth (Pedraza et al., 2010; Vacheron et al., 2013; Gomez et al., 2014), yield (Dobbelaere et al., 2001; Costa, 2015), nitrogen content in plants (Richard et al., 2018), nitrogen fixation (Bashan and De-Bashan, 2010), radical proliferation and development of hormonal activities (Bashan and De Bashan, 2010; Cassán et al., 2011; Cohen et al., 2015). In recent years, there has been a concern about this species regarding the capacity for survival and degradation of commercially used xenobiotics. Some authors have shown that Azospirillum can survive to the presence of herbicides and they can degrade xenobiotics (Travaglia et al., 2015; Singh and Singh, 2016). One of the most studied species corresponds to $A$. brasilense, particularly to the strain Az39 that is isolated from the rhizosphere of wheat in Argentina. This strain was selected for its efficiency to promote the growth of this crop and has been distinguished for its capacity to increase yield and productivity in wheat and maize. These results led to the
National Agricultural Health Service (SENASA) together with companies producing inoculants, to recommend its formulation to be applied in seeds of numerous cereals and other crops (Cassán et al., 2015). In relation to this, there are commercial biofertilizers based on Azospirillum spp. However, its application is not always effective, which is why the use of native microorganisms is preferred. They adapt to the climatic conditions and can compete successfully with the native biota. For this reason, in this work, this strain is evaluated in a comparative way with the Sp7 strain. DNA homology studies indicated that within the species of $A$. brasilense, the Sp7 strain was the first described and it is considered as a strain of reference (Tarrand et al., 1978; Lin et al., 2015).

One of the crops in which this species is used as an inoculant is maize, which represents one of the most important sources of income for the agricultural sector in Argentina (Hallauer et al., 2010). However, there are various factors that affect its production. One of them is the competition that weeds exert and the control of them, in the great majority of cases, is achieved with the timely application of herbicides, which is an extended practice (Sannino and Gianfreda, 2001; Petcu et al., 2015). The use of transgenic varieties of this glyphosate tolerant crop has helped certain regions in which this herbicide is transformed into the 
compound used mainly to control the growth of weeds during the crop cycle (Bonny, 2016). It is one of the most mobile herbicides through the phloem and is especially effective against perennial weeds, as it accumulates in the tissues of stems, roots and storage organs. Its co-metabolic degradation depends on the microbiological activity of the soil. Nevertheless, over the years, the incorrect use of glyphosate caused a large number of weeds to resist to it. Currently, the objective is to use agrochemical mixtures that include glyphosate as the main and broad-spectrum herbicide together with other active residual ingredients (Metzler et al., 2016). Among the herbicides, one of the most used is atrazine that is derived from triazines (SalazarLedesma et al., 2018). Like glyphosate, biodegradation is one of the main processes responsible for the elimination of atrazine (Sene et al., 2010). Some studies evaluate the effects of glyphosate on rhizobacteria (Zabaloy et al., 2008; Aguirre-Cadena et al., 2014; Barriuso et al., 2011; Arango et al., 2014; Newman et al., 2016), although there is no evidence regarding the effects of atrazine in relation to Azospirillum. In turn, in conventional agriculture, inoculation of plant growth promoting rhizobacteria (PGPRs) at seed level is carried out, although its effectiveness depends on its characteristics and its interaction with the soil. In this sense, we have begun to investigate the effectiveness of the foliar application of biological formulations, since the incorporation of the inoculant pretends to take advantage of the intrinsic capacity of the bacteria to produce compounds with high biological activity, independently of the edaphic conditions (Zanettini and Puente, 2017). Based on this, a new proposal of inoculation at the time of sowing (seedtime) could be the sprinkling of these bacteria at leaf level, which would represent a new technological proposal (Di Palma et al., 2017). In addition, the use of these biological compounds has also reduced the application of chemical fertilizers in various crops (Alori and Babalola, 2018), which can contribute to lower costs, as well as being an alternative to the contamination of soil and subsoil by chemical fertilizers. This background generates the following question: Can the environmental problem generated by inputs for maize cultivation be solved with the use of PGPRs and application strategies? Based on this, a comparative study between the native strain (Az39) and the reference strain (Sp7) of $A$. brasilense was proposed, evaluating their effects on commercial herbicides like glyphosate and atrazine, both in vitro and in maize plants.

\section{Results}

\section{In vitro assays}

The survival capacity of both strains was different regarding the presence of glyphosate. It affected the growth of the Sp7 strain negatively, observing significantly lower OD values $(0.07 \pm 0.05)$ with respect to the control $(1.4 \pm 0.005)$ as well as with the viable cell counts $\left(0.63 \times 10^{4}\right.$ and $1.3 \times 10^{8}$ CFU mL ${ }^{-1}$, respectively) (Fig.1 a). On the contrary, in the case of strain Az39, this herbicide did not affect its growth when it was applied in its culture medium (OD control and glyphosate: $1.41 \pm 0.005$ and $96 \pm 0.002$ ). This strain was able to grow with the addition of glyphosate with a count of $1.2 \times 10^{11} \mathrm{CFU} \mathrm{\textrm {mL } ^ { - 1 }}$, achieving its maximum growth peak at $36 \mathrm{~h}$ of incubation, establishing a longer lag phase than the control treatment, although this treatment presented counts of the same order (Fig.1 b).
On the other hand, the use of the herbicide atrazine did not affect the growth of each strain, although strain Az39 achieved higher growth values with respect to Sp7. The reference strain showed an OD of $1.001 \pm 0.2$ with a count of $5.8 \times 10^{8} \mathrm{CFU} \mathrm{\textrm {mL } ^ { - 1 }}$ at $24 \mathrm{~h}$ of incubation, with similar values to the control, being the same as $0.9053 \pm 0.05$ and $2.8 \times 10^{8} \mathrm{CFU} \mathrm{^{-1 }}$. Contrarily, the native strain reached an OD of $1.22 \pm 0.05$ at $24 \mathrm{~h}$ incubation with a viable bacterial count of $1.9 \times 10^{11} \mathrm{CFU} \mathrm{mL}^{-1}$, whereas in the control, it was 1.4 and $2.1 \times 10^{11} \mathrm{CFU} \mathrm{mL}^{-1}$, respectively (Fig. 1).

\section{Herbicides as nutritional source}

In the assays carried out to evaluate whether this strain uses herbicides as a nutritional source, it was determined that $A$. brasilense Az39 was not able to use atrazine as a nitrogen source, given that after $70 \mathrm{~h}$ of incubation its growth in the liquid medium containing atrazine as the sole source of nitrogen was not observed. However, this strain was able to use the glyphosate-based herbicides as the sole carbon source, showing a slower growth compared to the control, with a longer lag phase of $12 \mathrm{~h}$, achieving its maximum growth peak at $60 \mathrm{~h}$ of incubation with a count of $10^{11} \mathrm{CFU}$ $\mathrm{mL}^{-1}$ (Fig. 1 b). The Sp7 strain was not able to survive neither use glyphosate as the sole carbon source nor atrazine as a nitroge source (Fig. 1 a).

\section{Maize plants assays}

In the assays carried out in plants under controlled conditions, glyphosate affected the aerial and root dry biomass negatively (Fig. 2), it affected the leaf area and the chlorophyll $a$ content, and increased the cell membrane damage with respect to the control without application of the herbicide (Table 1). Some of these effects, such as radical dry weight (Fig. 2 b) and the content of chlorophyll $a$ (Table 1), were ameliorated when they were sprayed with both strains, while in the measurements of the leaf area, only the native strain was able to increase significantly compared to the treatment with glyphosate without inoculation. In addition, Az39 was also able to diminish the membrane damage caused by this herbicide (Table 1).

With the application of atrazine, the maize plant decreased their radical dry weight (Fig. 2 b), the chlorophyll $a$ content and the foliar area (Table 1) with respect to the control without the application of the herbicide. In those treatments, where both the reference strain and the native strain were applied, the radical dry weight variable increased significantly (Fig. 2 b), while in the chlorophyll content, only the native strain had significantly higher values compared to the treatment with the herbicide without inoculation (Table 1). None of the strains was able to reverse the negative effect of the herbicide caused on the foliar area and on the cell membrane damage measurements (RCR \%) (Table 1).

Factorial design for both bacterial strains determined the absence of herbicide-bacterial strain interaction. In the plants inoculated with the reference strain Sp7, a negative effect was observed with the treatment of glyphosate compared with atrazine in all the variables presented (DWR (g): $0.08 \pm 4.1 \times 10^{-3} \mathrm{~b}: 0.09 \pm 0.01 \mathrm{a}$; DWAP (g): $0.14 \pm 0.01$ b: $0.20 \pm 0.01 \mathrm{a}$; FA $\left(\mathrm{cm}^{2}\right): 43.17 \pm 1.5$ b: $49.08 \pm 1.5 \mathrm{a}$; RCR (\%): $34.77 \pm 2.36: 25.56 \pm 3.34$ b). Chlorophyll content (mg g 1 FW) was higher in plants treated with glyphosate compared to those plants treated with atrazine (105.26 \pm 
Table 1. Content of chlorophylls $a\left(\mathrm{mg} \mathrm{g}^{-1} \mathrm{FW}\right)$, relative conductivity rate $(\% \mathrm{RCR})$ and foliar area $\left(\mathrm{cm}^{2}\right)$ of maize plants at 28 days post-sowing.

\begin{tabular}{lccc}
\hline Treatments & Chlorophylls $a\left(\mathrm{mg} \mathrm{g}^{-1} \mathrm{FW}\right)$ & RCR (\%) & Foliar area $\left(\mathrm{cm}^{2}\right)$ \\
\hline Control & $109.5 \pm 23.76^{\mathrm{a}}$ & $15.10 \pm 2.639^{\mathrm{c}}$ & $57.05 \pm 2.724^{\mathrm{a}}$ \\
$\mathrm{G}$ & $84.27 \pm 2.907^{\mathrm{c}}$ & $30.71 \pm 4.892^{\mathrm{a}}$ & $42.90 \pm 2.675^{\mathrm{c}}$ \\
$\mathrm{A}$ & $66.60 \pm 6.198^{\mathrm{d}}$ & $21.31 \pm 6.717^{\mathrm{ab}}$ & $48.10 \pm 1.952^{\mathrm{b}}$ \\
Sp7 & $150.0 \pm 29.44^{\mathrm{a}}$ & $16.45 \pm 3.530^{\mathrm{b}}$ & $55.78 \pm 1.916^{\mathrm{a}^{\mathrm{a}}}$ \\
Az39 & $95.12 \pm 5.152^{\mathrm{b}}$ & $24.26 \pm 2.745^{\mathrm{b}}$ & $56.60 \pm 2.031^{\mathrm{a}}$ \\
$\mathrm{G}+$ Sp7 & $106.1 \pm 17.74^{\mathrm{a}}$ & $33.00 \pm 2.315^{\mathrm{a}}$ & $44.46 \pm 1.629^{\mathrm{c}}$ \\
$\mathrm{G}+$ Az39 & $137.1 \pm 18.62^{\mathrm{a}}$ & $21.66 \pm 2.571^{\mathrm{b}}$ & $53.74 \pm 1.552^{\mathrm{b}}$ \\
A + Sp7 & $70.63 \pm 5.972^{\mathrm{d}}$ & $22.80 \pm 3.191^{\mathrm{b}}$ & $51.16 \pm 2.087^{\mathrm{b}}$ \\
A + Az39 & $77.34 \pm 8.883^{\mathrm{cd}}$ & $18.59 \pm 2.827^{\mathrm{bc}}$ & $51.23 \pm 1.099^{\mathrm{b}}$ \\
\hline
\end{tabular}

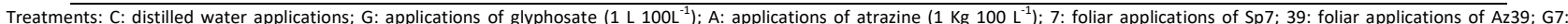
applications of glyphosate and Sp7; G39: applications of glyphosate and Az39; A7: applications of atrazine and Sp7; A39: applications of atrazine and Az39. Different letters on each column indicate statistically significant differences.

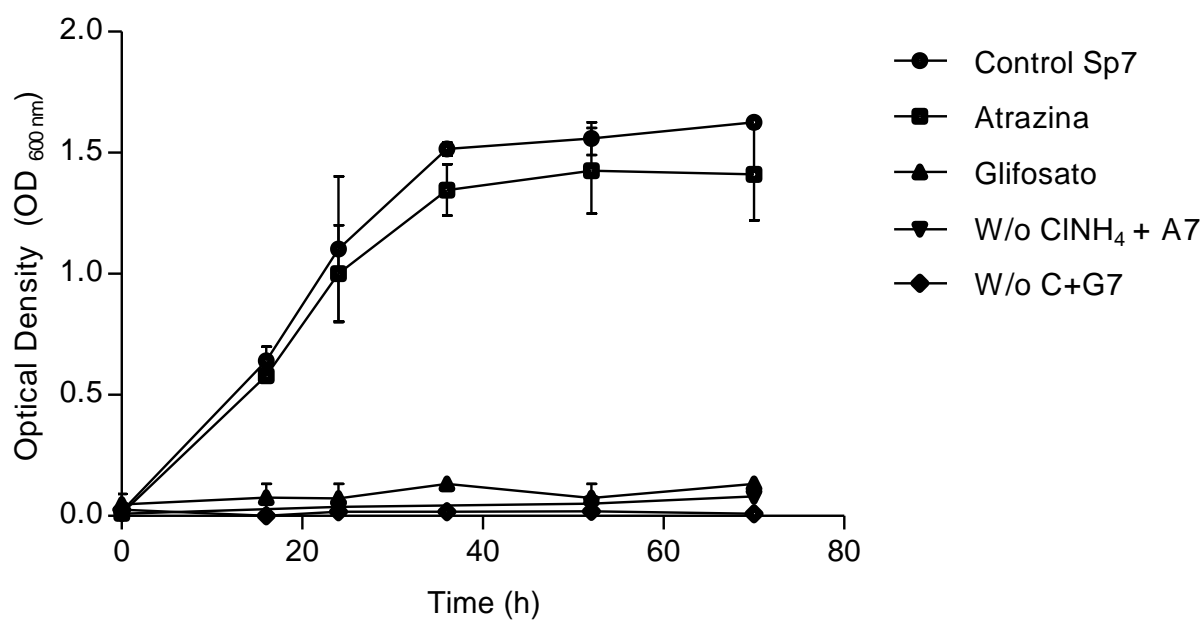

a)

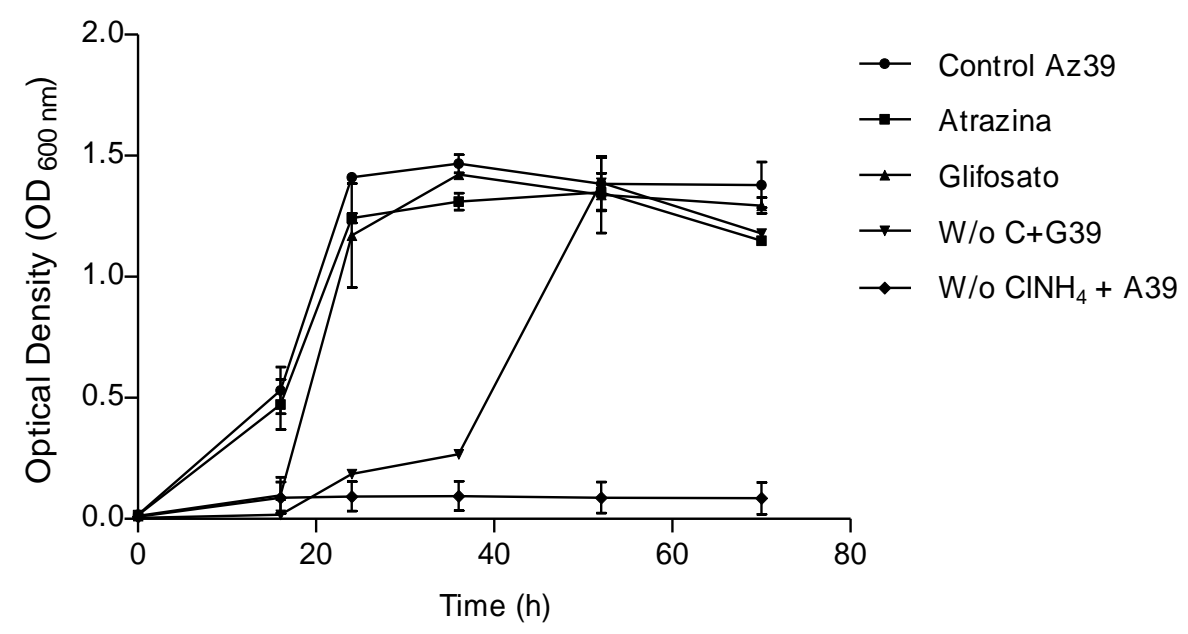

b)

Fig 1. Growth curves of two strains of Azospirillum brasilense. a) Sp7 in Fructose culture medium. Treatments: Sp7: control without herbicides (o); A7: + atrazine $\left(0.04 \mathrm{~g} \mathrm{~L}^{-1}\right)(\mathbf{\Delta})$; G7: + glyphosate $\left(0.5 \mathrm{~g} \mathrm{~L}^{-1}\right)$ (回); W/o $\mathrm{CINH}_{4}+\mathrm{A} 7$ : without addition of CINH $\mathrm{C}_{4}$ as source of $\mathrm{N}+$ atrazine $(\boldsymbol{\nabla})$; W/o C + G7: without addition of malic acid as a source of $\mathrm{C}+$ glyphosate $(0) ; \mathrm{b})$ Az39 in NFb culture medium. Treatments: Az39: control without herbicides (o); A39: + atrazine $\left(0.04 \mathrm{~g} \mathrm{~L}^{-1}\right)(\mathbf{\Delta}) ; \mathrm{G} 39$ : + glyphosate $\left(0.5 \mathrm{~g} \mathrm{~L}^{-1}\right)$ (回); W/o CINH + A39: without addition of $\mathrm{CINH}_{4}$ as a source of $\mathrm{N}+$ atrazine $(\mathbf{\nabla}) ; \mathrm{W} / \mathrm{o} \mathrm{C}+\mathrm{G} 39$ : without addition of malic acid as a source of $\mathrm{C}+$ glyphosate $(\diamond)$. 


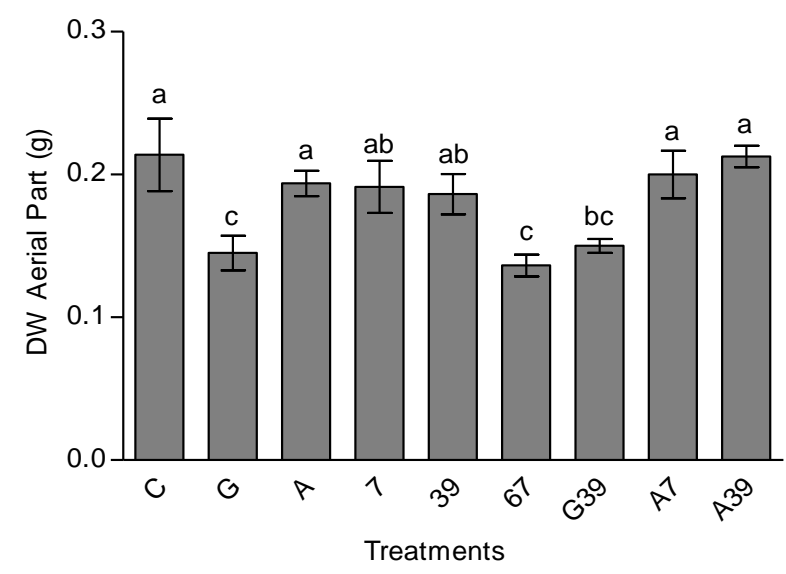

a)

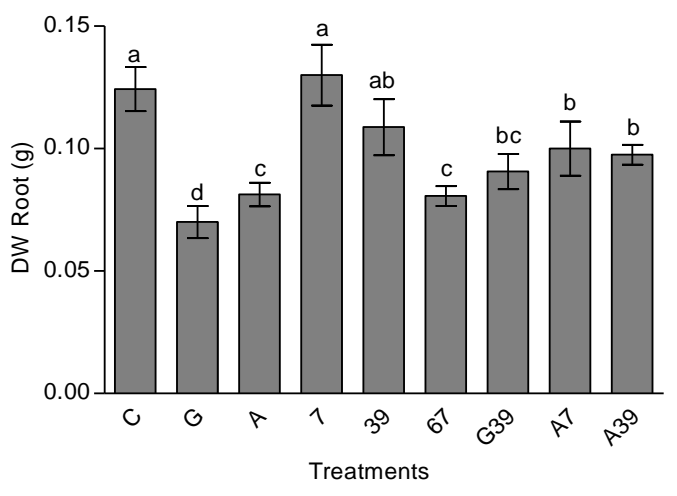

b)

Fig 2. Dry weight (g) of aerial part (a) and root (b) of maize plants 28 days after sowing. Treatments: C: distilled water applications;

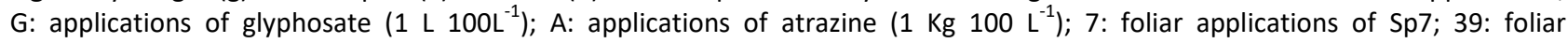
applications of Az39; G7: applications of glyphosate and Sp7; G39: applications of glyphosate and Az39; A7: applications of atrazine and Sp7; A39: applications of atrazine and Az39. Different letters on each bar indicate statistically significant differences $(p<0.05)$.

7.94 a: $70.10 \pm 8.37 \mathrm{~b}$, respectively). In radical biomass, a beneficial effect of the inoculation was observed (inoculated: $0.09 \pm 4.9 \times 10^{-3}$ a; uninoculated: $0.08 \pm 4.9 \times 10^{-}$ 3 b). In plants treated with the native strain Az39, a beneficial effect of inoculation was observed in DWR (g) $(0.09 \pm 0.01$ a: $0.08 \pm 0.01 \mathrm{~b})$, chlorophylls $a\left(\mathrm{mg} \mathrm{g}^{-1} \mathrm{FW}\right)(104$ \pm 8.05 a : $76.89 \pm 9$ b), foliar area $\left(\mathrm{cm}^{2}\right)(51.74 \pm 1.35 \mathrm{a}$ : $45.04 \pm 1.35 \mathrm{~b})$ and RCR (\%) $(21.76 \pm 2.85 \mathrm{~b}: 31.61 \pm 2.79 \mathrm{a})$, compared to uninoculated plants.

\section{Discussion}

The ability of $A$. brasilense Az39 to survive at the presence of commercial herbicides like glyphosate and atrazine under the doses tested was demonstrated. The ability to use glyphosate as the sole source of carbon has also been proved. From the ecological point of view, this is an important factor taking into account that the use of these chemicals would not affect the population of the bacterial strain, and that glyphosate could be metabolized by the bacterium with its consequent removal from the environment. In relation to this, the experiments of AguirreCadena et al. (2014) also adhere to this idea. They observed that when applying glyphosate, the population of Azospirillum in the rhizosphere of wheat plants did not decrease and was even higher in the presence of this herbicide. Similar results are cited by Zabaloy et al. (2008), affirming a stimulation of the microbial activity after the application of glyphosate, mediated by carbon and nitrogen mineralization, without affecting the microbial biomass of the soil. Schlatter et al. (2017) found that repeated glyphosate applications had minimal impacts on soil and rhizosphere bacterial community composition and diversity. The in vitro capacity of the bacterium to tolerate the presence of this herbicide in its commercial (isopropylamine salt of $\mathrm{N}$-phosphonomethyl glycine) and non-commercial formula (Isopropylamine salt) and the capacity to degrade it when it was introduced in their environment as an additional source of carbon in low concentrations was observed (Travaglia et al., 2015). However, many authors (Zablotowicz and Reddy, 2004; Zobiole et al., 2010; Martínez-Nieto et al., 2011; Nandula and Tyler, 2016) point out that the use of these chemicals is detrimental to the viability of rhizosphere bacteria, among them, those corresponding to the group of biological nitrogen fixers. In this sense, the results obtained in this study can be related to those obtained by the authors mentioned previously, indicating that the reference strain (Sp7) could be within that group in which its viability in the presence of glyphosate is affected. This highlights the importance of the use of native strains such as Az39 since it can survive the presence of both herbicides tested in this work. This gives an adaptive advantage over other strains, probably due to the region in which it was isolated with a history of application of these agrochemicals. This supports the assertion by Garcia et al. (2010), indicating that although there are commercial 
biofertilizers of Azospirillum spp., its application is not always effective, highlighting the use of native microorganisms adapted to the conditions of the area. Similar studies carried out in the presence of glyphosate and herbicide tolerant Burkholderia cepacia PSBB1 when used as bioinoculant, safeguarded the plants from the inhibitory effect of glyphosate and concomitantly augmented the whole dry matter production, nutrient accumulation and seed attributes of chickpeas. Interestingly, the ability of strain PSBB1 to excrete such growth enhancers was not eliminated completely even at higher glyphosate concentration (Shahid and Khan, 2018).

On the other hand, in the trials referring to the use of atrazine as the sole source of nitrogen, it should be noted that no results have been published with bacteria of the genus Azospirillum and its behavior towards atrazine. Furthermore, bacteria of this genus have not been isolated in studies of isolation of microorganisms from soils exposed to this herbicide. However, it is interesting to highlight the survival capacity of both strains when exposed to this agrochemical, as long as they could survive nutritionally at the expense of other essential sources, thus constituting a new contribution in relation to this bacterial genus.

Plant growth promoting bacteria stand out for their potential as biofertilizers, constituting an agroecological and sustainable alternative. Because of this, it is necessary to design experiments on the long-term effect of pesticides on microbial communities and their eco-toxicological effects; since it is widely known that pesticides and their use can cause serious hazards to soil environment and human health (Meena et al. 2020). This has become critical because most harmful effects are caused by the application doses that exceed the recommended rates. In this sense, based on the novel results of this study, in our work group (Cardozo et al., in preparation) effects of the bioinoculation of $A$. brasilense Az39 in field crop maize with different combinations and doses of herbicides are evaluated. This is done in order to increase production and to improve sustainable management practices. The education of farmers, distributors, industry, policymakers, and other stakeholders in the discriminate use of pesticides is critical to reducing the adverse effects they have on humans and the environment.

\section{Materials and methods}

\section{Microorganisms and in vitro experimental design}

The bacterial strains Az39 and Sp7 were provided by the agronomist A. Perticari, IMIZA-INTA-Castelar, Argentina and Dr. Y. Okon, Fac. Agriculture, Food and Environment of the Hebrew University of Jerusalem. The survival capacity of both strains was determined regarding the presence of glyphosate (monoammonium salt or N-phosphonomethylglycine dimethylamine, Panzer Gold, Dow Agrosciences) and atrazine (2-chloro-4-ethylamine-6-isopropylamine, Gesaprim 90 WC, Syngenta), adding them to the culture medium from the beginning of their growth. The recommended culture medium for each strain was NFb (Dobereuier et al., 1976) for Az39, Fructose (Reem et al., 2015) for Sp7 and NFbCongo Red (Rodríguez Cáceres, 1982) for both. The doses of glyphosate and atrazine were $0.5 \mathrm{~g} \mathrm{~L}^{-1}$ and $0.04 \mathrm{~g} \mathrm{~L}^{-1}$, corresponding to 0.2 and $0.4 \%$ of the dose used in the field, selected according to previous trials in the work group (Travaglia et al., 2015). The ability to use herbicides as the sole source of carbon or nitrogen was also evaluated
(Moneke et al., 2010; Martínez-Nieto et al., 2012; Pinelli et al., 2012). For this, each culture medium was prepared without the addition of malic acid (Az39) or fructose (Sp7) as a carbon source and without ammonium chloride as a source of nitrogen. These were replaced by glyphosate and atrazine using the doses mentioned above. The $\mathrm{pH}$ was adjusted to $6.8-7.0$ before sterilization $\left(1 \mathrm{~atm}, 121{ }^{\circ} \mathrm{C}, 20\right.$ $\mathrm{min})$. The treatments corresponding to the $\mathrm{Sp7}$ strain were: Sp7: control without herbicides; A7: Fructose medium + atrazine; G7: Fructose medium + glyphosate; W/o $\mathrm{CINH}_{4}+$ A7: Fructose medium without addition of $\mathrm{CINH}_{4}$ as a source of $\mathrm{N}+$ atrazine; W/o C + G7: Fructose medium without addition of malic acid as a source of $\mathrm{C}+$ glyphosate. While those corresponding to the Az39 strain were: Az39: control without herbicides; A39: NFb medium + atrazine; G39: NFb medium + glyphosate; W/o $\mathrm{CINH}_{4}+\mathrm{A} 39: \mathrm{NFb}$ medium without addition of $\mathrm{CINH}_{4}$ as a source of $\mathrm{N}+$ atrazine; W/o C + G39: NFb medium without addition of malic acid as a source of C + glyphosate.

The growth was monitored by $70 \mathrm{~h}$ incubation $\left(28^{\circ} \mathrm{C}\right.$ and $140 \mathrm{rpm})$ measuring its optical density $\left(\mathrm{OD}_{600} \mathrm{~nm}\right)$ and its purity through the Gram stain technique. Fresh mobility and viability was determined by measuring the number of colony-forming units (CFU mL ${ }^{-1}$ ) in NFb-Congo Red Medium, with visualization of characteristic colonies. Data obtained the in vitro assays were from three repetitions $(n=3)$ and the values are recorded as the mean standard error of each group of results. The comparisons between the different treatments were carried out using ANOVA.

\section{Plant materials and experimental design}

The modern maize hybrid DK7210 VT3pro was used, which is the recommended for the maize area of Argentina. The plants were incubated in a growth chamber under controlled conditions ( $16 \mathrm{~h}$ light / $8 \mathrm{~h}$ darkness, $25^{\circ} \mathrm{C}, 80 \%$ relative humidity). The treatments consisted of applications by irrigation of glyphosate and atrazine $\left(1 \mathrm{~mL} \mathrm{~L}^{-1}\right.$ and $1 \mathrm{~g} \mathrm{~L}^{-1}$, corresponding to 4 and $5 \%$ of the doses used in the field, respectively) in two phenological stages: V2 and V4 (Ritchie and Hanway, 1982) with and without the foliar inoculations of the different strains of $A$. brasilense. The treatments were: C) distilled water applications; G) applications of glyphosate; A) applications of atrazine; 7) foliar applications of Sp7; 39) foliar applications of Az39; G7) applications of glyphosate and Sp7; G39) applications of glyphosate and Az39; A7) applications of atrazine and Sp7; A39) applications of atrazine and Az39.

In V6 (about 25 days post sowing), the following morphophysiological variables were determined. Aboveground and belowground biomass was determined on a dry weight (DW) by incubation in an oven at $60^{\circ} \mathrm{C}$, until reaching a constant weight. Foliar area was determined by multiplying the total length by the maximum width of each leaf. The result was multiplied by the particular correction factor for each crop (Ahmad et al., 2015). Chlorophyll a measurement was determined by extraction in $80 \%$ ethanol according to the method of Vernon and Mac Kinney (modified by Mac Kinney, 1938). Damage of cell membranes was evaluated as the relative conductivity rate (RCR) according to Prásil and Zámecník (1998). For this, $0.1 \mathrm{~g}$ of fresh material was weighed and placed in distilled water at $4{ }^{\circ} \mathrm{C}$ for 24 hours. After that time, measurements of electrical conductivity were taken in the solution at $25^{\circ} \mathrm{C}$. Data were obtained in the plant materials from three repetitions $(n=8)$ and the 
values were given as the mean standard error of each group of results.

\section{Statistical analysis}

The comparisons between the different treatments were carried out using ANOVA. Fisher's LSD test was used to establish the significance of differences between groups and factorial analysis to shed light on the effect of each strainherbicide interaction. The significance level in all cases was set at $p<0.05$ when compared between different results. The results were analyzed using the GraphPad Prism statistical analysis software package (professional version 5.0.3.0 GraphPad Prism).

\section{Conclusions}

The strain Azospirillum brasilense Az39 survives to the presence of both commercial herbicides and uses glyphosate as the sole source of carbon. The strain of Azospirillum brasilense Sp7 only survives in the presence of atrazine. Both strains are capable of ameliorating the damaging effects of herbicides at the root level in maize plants. Most of the negative effects of both herbicides on these plants are attenuated only with foliar inoculation of the native strain. Therefore, the native strain of $A$. brasilense Az39 has better adaptive characteristics against herbicides widely used in maize. This highlights the importance of the use of native microorganisms for effective inoculations in crops.

\section{Acknowledgments}

This work was funded by Secretaría de Ciencia y TecnologíaUniversidad Nacional de Río Cuarto (SECYT-UNRC) and Consejo Nacional de Investigaciones Científicas y Técnicas (CONICET). The experiments described in this article were developed in UNRC-INIAB.

\section{References}

Aguirre Cadena J, Reyna Téllez S, Cuautle M, Aguirre Medina J (2014) Sobrevivencia de Azospirillum brasilense después de aplicar herbicidas en Triticum aestivum L. Var. Altiplano. Rev Mex Cienc Agríc. 5:1549-1555.

Ahmad S, Ali H, Ur Rehman A, Zeb Khan RJ, Ahmad W, Fatima Z, Abbas G, Irfan M, Ali H, Khan MA, Hasanuzzaman M (2015) Measuring leaf area of winter cereals by different techniques: A Comparison. Pak J Life Soc Sci. 13(2): 117-125.

Alori ET, Babalola OO (2018) Microbial Inoculants for Improving Crop Quality and Human Health in Africa. Front Microbiol. 9: 2213.

Arango L, Buddrus-Schiemann K, Opelt K, Lueders T, Haesler F, Schmid M, Ernst D, Hartmann A (2014) Effects of glyphosate on the bacterial community associated with roots of transgenic Roundup Ready ${ }^{\circledR}$ soybean. Eur J Soil Biol. 63: 41-48.

Barriuso J, Marín S, Mellado RP (2011) Potential Accumulative Effect of the Herbicide Glyphosate on Glyphosate-Tolerant Maize Rhizobacterial Communities over a Three-Year Cultivation Period. PLoS ONE. 6(11): e27558.
Bashan Y, De Bashan LE (2010) How the plant growthpromoting bacterium Azospirillum Promotes Plant GrowthA Critical Assessment. Adv Agron. 108:77-136.

Bonny S (2016) Genetically Modified Herbicide-Tolerant Crops, Weeds, and Herbicides: Overview and Impact. Environ Manage. 57(1):31-48.

Cassán F, Perrig D, Sgroy V, Luna V (2011) Basic and Technological Aspects of Phytohormone Production by Microorganisms: Azospirillum sp. as a Model of Plant Growth Promoting Rhizobacteria. In: Maheshwari DK (ed) Bacteria in Agrobiology: Plant Nutrient Management. SpringerLink: Bücher. New York. 141-182.

Cassán FD, Okon Y, Creus CM (2015) Protocol for the Quality Control of Azospirillum spp. Inoculants. In: Cassán, Fabricio Dario, Okon, Yaacov, Creus, Cecilia M. (eds). Handbook for Azospirillum: Technical Issues and Protocols. 1: 487-499.

Cohen A, Bottini R, Pontin M, Berli F, Moreno D, Boccalandro $\mathrm{H}$, Travaglia C, Piccoli P (2015) Azospirillum brasilense ameliorates the response of Arabidopsis thaliana to drought mainly via enhancement of ABA levels. Physiol Plant. 153: 79-90.

Costa RRGF, Quirino G, Naves DC, Santos CB, RochaAN (2015) Efficiency of inoculant with Azospirillum brasilense on the growth and yield of second-harvest maize. Pesq Agropec Trop (45): 304-311

Di Palma MA, Cardozo P, Martin S, Dardanelli MS, Reinoso H, Travaglia C (2017) Estudio comparativo del comportamiento de dos cepas de Azospirillum brasilense frente al herbicida glifosato. Paper presented at the XXI Jornadas de la Sociedad de Biología de Córdoba, La Falda, Córdoba, 10-12 August 2017.

Dobbelaere S, Croonenborghs A, Thys A, Ptacek D, Vanderleyden J, Dutto P, Labandera-Gonzalez C, Caballero Mellado J, Aguirre J, Kapulnik Y, Berner S, Burdman S, Kadouri D, Sarig $S$ and Okon Y (2001) Responses of agronomically important crops to inoculation with Azospirillum. Aust J Plant Physiol. 28: 871-879.

Dobereiner J, Marriel IE, Nery M (1976) Ecological distribution of Spirillum lipoferum Beijerinck. J Microbiol. 10: 1464-73.

García JE, Maronicheb G, Creus C, Suárez-Rodríguez R, Ramirez-Trujillo JA, Groppa MD (2017) In vitro PGPR properties and osmotic tolerance of different Azospirillum native strains and their effects on growth of maize under drought stress. Microbiol Res. 202: 21-29.

García L, Igrassia H, Kalnay P (2010) Control combinado de plagas en MAIZ Maíz VT Triple PRO. Boletín Técnico. DEKALB RINDE. http://docplayer.es/1147428-Boletintecnico-control-combinado-de-plagas-en-maiz-maiz-vttriple-pro.html .

Gómez M, Mercado E, García Pineda E (2014) Azospirillum una rizobacteria con uso potencial en la agricultura. Biológicas. 16(1):11-18.

Hallauer AR, Carena MJ, Miranda JB (2010) Quantitative genetics in maize breeding. In: Springer (ed). Handbook of plant breeding. $2^{\text {nd }}$ ed. NewYor, NY. 8: 267-298.

Lin S, Hameed A, Liu Y, Hsu Y, Lai W, Shen F, Young C (2015) Azospirillum soli sp. nov., a nitrogen-fixing species isolated from agricultural soil. Int J Syst Evol Microbiol. 65: 46014607.

Mac Kinney G (1938) Some absorption spectra of leaf extract. Plant Physiol. 13:128-140.

Martínez Nieto P, Bernal Castillo J, Agudelo Fonseca E, Bernier López S (2012) Tolerancia y degradación del glifosato por bacterias aisladas de suelos con aplicaciones 
frecuentes de Roundup $\mathrm{SL}^{\circledR}$. Revista Pilquen. Sección Agronomía. Año XIV. № 12.

Martínez Nieto P, Castillo Bernal J, Torres Romero L (2011) Efectos del glifosato sobre microorganismos diazotroficos y nitrificantes en ecosistemas alto andino y seco tropical colombianos. Revista Pilquen. Sección Agronomía. Año XIII. № 11.

Meena RS, Kumar S, Datta R, Lal R, Vijayakumar V, Brtnicky M, Sharma MP, Yadav GS, Jhariya MK, Jangir CK, Pathan SI, Dokulilova T, Pecina V, Marfo TD (2020) Impact of Agrochemicals on Soil Microbiota and Management. Land. 9(2), 34

Mehnaz S (2015) Azospirillum: A Biofertilizer for Every Crop. In: Naveen Kumar Arora (ed). Plant Microbes Symbiosis: Applied Facets. India. 297-314.

Metzler M J, Ahumada M (2016) Evaluación de herbicidas residuales preemergentes para el control de Echinochloa crus-galli en Entre Ríos. Serie de extensión INTA EEA Paraná.

https://inta.gob.ar/sites/default/files/inta control echino chloa crus galli metzler ahumada.pdf

Moneke AN, Okpala GN, Anyanwu CU (2010) Biodegradation of glyphosate herbicide in vitro using bacterial isolates from four rice fields. Afr J Biotechnol. 9 (26): 4067-4074.

Nandula VK, Tyler HL (2016) Effect of new auxin herbicide formulations on control of herbicide resistant weeds and on microbial activities in the rhizosphere. Am J Plant Sci. 7(17):2429-2439.

Newman MM, Hoilett N, Lorenz N, Dick RP, Liles MR, Ramsier C, Kloepper JW (2016) Glyphosate effects on soil rhizosphere-associated bacterial communities. Sci Total Environ. 543(Pt A):155-160.

Pedraza R, Teixeira K, Fernández Scavino A, García de Salamone I, Baca B, Azcón R, Baldani V, Bonilla R (2010) Microorganismos que mejoran el crecimiento de las plantas y la calidad de los suelos. Revisión. Corpoica Cienc Tecnol Agropecu. 2:155-164.

Petcu V, Oprea G, Ciontu C, Stefanic G (2015) Studies on the effect of some herbicides (single and different mixtures) on weeds control and soil quality in maize. Rom Agri Res. 32:245-252.

Pinelli L, Da Cunha J, Bellini M, Fernandez Scavino, A (2012) Selección y caracterización de consorcios de bacterias como herramientas de biorremediación de la contaminación por atrazina en plantas potabilizadoras de agua. Paper presented at the $7^{\text {th }}$ Congreso de Medio Ambiente AUGM, La Plata, 22-24 may 2012.

Prázil L, Zámecník J (1998) The use of a conductivity measurement method for assessing freezing injury. Influence of leakage time, segment number, size and shape in a sample on evaluation of the degree of injury. Environ Exp Bot. 40:1-10.

Reem G, Burdman S, Okon Y (2015) Methods for Studying Phenotypic Variation

in Azospirillum. In Cassán et al. (eds.), Handbook for Azospirillum. 231-239.
Richard PO, Adekanmbi AO, Ogunjobi AA (2018) Screening of bacteria isolated from the rhizosphere of maize plant (Zea mays L.) for ammonia production and nitrogen fixation. Afr J Microbiol Res. 34:829-834.

Ritchie S, Hanway JJ (1982) How a corn plant develops. lowa State Univ Technol. Spec Rep. 48.

Rodríguez Cáceres E (1982) Improved medium for isolation of Azospirillum spp. Appl Environ Microbiol. 44: 990-991.

Salazar-Ledesma M, Prado B, Zamora O, Siebe C (2018) Mobility of atrazine in soils of a wastewater irrigated maize field. Agric Ecosist Environ. 255: 73-83.

Sannino F, Gianfreda L (2001) Pesticide influence on soil enzymatic activities. Chemosphere. 22:1-9.

Schlatter DC, Yin C, Hulbert S, Burke I, Paulitz T (2017) Impacts of repeated glyphosate use on wheat-associated bacteria are small and depend on glyphosate use history. Appl Environ Microbiol. 83(22): 01354-17.

Sene L, Converti A, Ribeiro Secchi G, Garcia Simão R (2010) New aspects on atrazine biodegradation. Braz Arch Biol Technol. (53)2: 1516-8913.

Shahid M, Khan MS (2018) Glyphosate induced toxicity to chickpea plants and stress alleviation by herbicide tolerant phosphate solubilizing Burkholderia cepacia PSBB1 carrying multifarious plant growth promoting activities. 3 Biotech. 8(2): 131.

Singh B, Singh K (2016) Microbial degradation of herbicides. Crit Rev Microbio. 42(2):245-61.

Tarrand J, Krieg NR, Döbereiner J (1978) A taxonomic study of the Spirillum lipoferum group, with descriptions of a new genus, Azospirillum gen. nov. and two species, Azospirillum lipoferum (Beijerinck) comb. nov. and Azospirillum brasilense sp. nov. Can J Microbiol. 8:967-80.

Travaglia C, Marcheti G, Masciarelli O, Fortuna J, Lucero M, Cardozo P, Reinoso H (2015) Towards sustainable maize production: Glyphosate detoxification by Azospirillum sp and Pseudomonas sp. Crop Prot. 77:102-109.

Vacheron J, Desbrosses G, Bouffaud M, Touraine B, MoënneLoccoz $Y$, Muller $D$, Legendre L, Wisniewski-Dyé F, PrigentCombaret C (2013) Plant growth-promoting rhizobacteria and root system functioning. Front Plant Sci. 4:356.

Zabaloy C, Garland L, Gómez M (2008) An integrated approach to evaluate the impacts of the herbicides glyphosate, 2, 4-D and metsulfuron-methyl on soil microbial communities in the Pampas region, Argentina. Appl Soil Ecol. 40:1-12.

Zablotowicz RM, Reddy KN (2004) Impact of glyphosate on the Bradyrhizobium japonicum symbiosis with glyphosateresistant transgenic soybean: a minireview. J Environ Qual. 3:825-31.

Zanettini JL, Puente M (2017) Inoculación foliar con Azosirillum brasilense en trigo. Artículo de divulgación Instituto Nacional de Tecnología Agropecuaria (INTA). 10:35.

Zobiole LHS, Oliveira Junior RS, Kremer RJ, Constantin J, Yamada T, Castro C, Oliveira Junior A (2010) Effect of glyphosate on symbiotic $\mathrm{N}_{2}$ fixation and nickel concentration in glyphosate-resistant soybeans. Appl Soil Ecol. 44:176-180. 